\title{
Seroprevalence of human immunodeficiency virus in a patient population of North of Portugal
}

\section{Fernanda Leite*, Fátima Oliveira, Ana Mota, Francisco Dias, Carla Ferreira and Adelina Marques}

\author{
Address: Clinical Haematology, Hospital Santo António, Porto, Portugal \\ Email: Fernanda Leite* - fernandajtleite@hotmail.com \\ * Corresponding author
}

from 2006 International Meeting of The Institute of Human Virology Baltimore, USA. 17-21 November, 2006

Published: 2I December 2006

Retrovirology 2006, 3(SuppI I):P35 doi:10.1 I86/1742-4690-3-SI-P35

(C) 2006 Leite et al; licensee BioMed Central Ltd.

\section{Background}

We intended to study the prevalence of HIV infection in our patient population and to compare with the result published before in a smaller population [1].

\section{Materials and methods}

We studied 13,023 patients tested for anti-HIV $1 / 2$ between 1/5/2004 and 31/12/2005, belonging to Hospital Santo António (HGSA), to an Infection Disease Hospital (HJU), to an HIV Testing Center (HTC) and other hospitals from North of Portugal (HNP). The test systems for screening was HIV Vitros Eci-software version 3.0 (in 90\% of cases) or Axsym ${ }^{\circledR} \mathrm{HIV} \mathrm{Ag} / \mathrm{Ab}$ Combo Abbott or Architect $^{\circledR}$ HIV Ag/Ac Combo Abbott (10\% of the cases). The reactive samples were confirmed with the supplemental test Inno-Lia ${ }^{\mathrm{TM}}$ HIV I/II-Innogenetics.
We find 705 individuals HIV-1 positive, 9 cases infected with HIV-2 and 19 classified as HIV positive.

\section{Conclusion}

We found an overall seroprevalence of HIV infection of $5,6 \%$. Last year our work had shown an HIV seroprevalence of $6,5 \%$ in a smaller population. *

\section{References}

I. Leite $F$, et al:: Two different test systems for detecting antiHIV and anti-HCV antibodies. Transfusion 2005, 45(Suppl):97A-98A.

\section{Results}

The results are shown in Table 1.

Table I:

\begin{tabular}{|c|c|c|c|c|}
\hline Institution & $\begin{array}{l}\text { Number of Individuals } \\
\text { Studied }\end{array}$ & Percentage of Population & Individuals HIV positive & $\begin{array}{l}\text { HIV seroprevalence } \\
\text { percentage }\end{array}$ \\
\hline HGSA & 9477 & 72,8 & 201 & 2,1 \\
\hline HJU & 1267 & 9,7 & 451 & 35,6 \\
\hline HTC & 2162 & 16,6 & 57 & 2,6 \\
\hline HNP & 117 & 0,9 & 24 & 20,5 \\
\hline
\end{tabular}

